\title{
Svetlana Hristova
}

\section{THE EUROPEAN MODEL OF CULTURAL HERITAGE POLICY}

\begin{abstract}
In order to understand the specificity of the European model of cultural heritage policy, we shall first take account of the main changes in the late modern world which pre-determined the repositioning of culture and cultural heritage in the world economy; then we shall trace the reasons leading to the current reappraisal of cultural heritage in European public policies, and finally we shall reveal the main trends in the European policies for cultural heritage, which form a distinguishable, coherent long-term approach that presumably can be qualified as 'the European model'.
\end{abstract}

SŁOWA KLUCZE: europeizacja dziedzictwa kulturowego, konstruowanie europejskiego dziedzictwa kulturowego, aktywizacja społeczna mieszkańców, zarządzanie partycypacyjne

KEY WORDS: europeanisation of cultural heritage, heritagisation of the European culture, urbactivism, participatory governance

\section{Living in a risk society}

There are several fundamental changes which took place in the world since the second half of the twentieth century described as a shift to consumerist, postindustrial, postmodern, and even - posthuman society. Certainly, a new symbolic economy based on tourism, media and entertainment began to develop when "with the disappearance of local manufacturing industries and periodic crisis in government and finance, culture is more and more the business of cities." This happened partially because the urban condition became ubiquitous - as it was prognosticated by Henri Lefebvre in his prominent work Urban Revolution originally published in 1970. Almost half century ago under the influence of the revolutionary events of 1968, Lefebvre advanced in his book the hypothesis that the perturbations we face and the changes they mark can be described as emerging 'urban society', characterised not simply

${ }^{1}$ S. Zukin, The Cultures of Cities, Oxford and Malden MA 1995, p. 2. 
by the concentration of population in cities, and even not by the extension of the urban fabric beyond its borders and corrosion of the residue of agrarian life, but by the total dominance of the city over the country, marking new social contradictions and growing inequalities which changed the whole paradigm of our living. From that moment on the crisis seemed to become our permanent condition.

One of the most overarching definitions of this changing reality was given by the German sociologist Ulrich Beck who in his homonymous book, originally published in 1986, gave a warning that humanity was entering into a risk society, Risikogesellschaft. With this notion he described a new stage of modernity when human civilization began to produce globally greater risks than wealth, unmanageable (ecological, economic, social, and military) risks questioning the existence of humanity itself. ${ }^{2}$ This meant not only a new global scale of misbalances between the minorities who capitalise the exploitation of nature and the rest of the world left without prospects for future, but a deadlock situation when nobody can be a winner because nobody can hide from these risks, therefore ultimately all are losers, rich and poor, developed and developing countries.

The political respond to the threat of perishability of human civilization was given by a report, commissioned by the UNO, known today as the Brundtland report after the name of the chair of the entitled committee - Gro Harlem Brundtland. Symptomatically, the report was named Our Common Future, ${ }^{3}$ addressing the trends that the planet and its people cannot long bear.

\section{Our Common Future}

Given the interrelatedness between all stakeholders - nation-states, huge corporations, cities and local governments, the only possible future, according to the report, is the shared one - not only in the redistribution of the economic gains and losses, but in all wide-ranging results and consequences of human deeds in order to prevent the ultimate destruction of the life on our planet. For a first time the necessity to take a new course of development - to sustainability was publicly declared.

This also determined the new role of cities and their culture in the revised developmental model in which cities were foreseen to become central arenas for tackling problems of sustainable development. Ultimately, the report suggested a new developmental path, by changing radically its main goal (human needs, and not pure profit), and by resetting the direction of urbanization, by "taking the pressure off the largest urban centres and building up smaller towns and cities, more closely integrating them with their rural hinterlands." ${ }^{4}$ Certainly, this can be observed today in urban Eu-

2 U. Beck, Risk Society: Towards a New Modernity, New Delhi 1992.

3 World Commission on Environment and Development (WCED), Our Common Future. Report of the Brundtland Commission, Oxford 1987.

${ }^{4}$ Ibidem, p. 73. 
rope where the small and medium-sized cities prevail not only in numbers, but they also constitute the backbone of European economy. ${ }^{5}$

The report also underlined the necessity of good city management closely related to the idea of decentralisation of funds, political power, and personnel to local authorities, which are best placed to appreciate and manage local needs. ${ }^{6}$ There is also an implicit vision of what is called today participative urban cultures referring to new forms of urban governance: "the sustainable development of cities will depend on closer work with the majorities of urban poor who are the true city builders, tapping the skills, energies and resources of neighbourhood groups and those in the 'informal sector'," in other words - the sector of non-governmental organizations and non-profit activities which canalize and organize the civic energy and will-power. This sector is sometimes called also social and solidarity economy, and it has a lot to do with the current needs of culture to be sustained using the resources of different forms of cooperation - cooperatives, mutual benefit societies, associations, foundations, social enterprises and networks.

Finally, although the report did not address explicitly the issues of culture, nevertheless it implied the vision of culture as value promoter, new pattern maker and mindset changer. In this far-reaching vision it suggested a whole system of new values, "to help individuals and nations cope with rapidly changing social, environmental, and development realities"8 to limit consumption patterns, and to reconcile humans with nature. By implicitly recognising the power of culture to shape human thinking through implanting the new values of sustainability, it prepared the ground for new specific policies based on explicit conceptualisation of the role of culture and cultural heritage to sustainable development.

\section{The European Path to Sustainable Cultural Heritage}

Such clear political statement is made in the Faro Convention adopted by the Council of Europe in 2005, which introduced the broadest possible definition of cultural heritage as an ever growing entity, accentuating on its flexibility, based on a public consensus which evolves along the evolving values and changing symbolic orders of society:

Cultural heritage is a group of resources inherited from the past which people identify, independently of ownership, as a reflection and an expression of their constantly evolving values,

${ }^{5}$ S. Hristova, We, European cities and towns: the role of culture for the evolving European model of urban sustainability [in:] Hristova et al. (Eds.), Culture and Sustainability in European Cities: Imagining Europolis, Lodon and NewYork 2015, pp. 47-50.

${ }^{6}$ Ibidem, p. 74.

7 Ibidem.

${ }^{8}$ Ibidem, pp. 44-45. 
beliefs, knowledge and traditions. It includes all aspects of the environment resulting from the interaction between people and places through time. ${ }^{9}$

On the other hand, the Convention opens also a door to inter-/trans-nationalisation of the national heritages through the enlarging community of connoisseurs and admirers, the transborder heritage community. The new philosophy forwarded in the Convention also stimulated the development of new approaches to cultural heritage, which is supposed not only to educate by giving evidence about the past, but also to create new social opportunities for local communities in terms of green jobs and businesses. Briefly, nowadays heritage is challenged to work for people as a public asset, and not to be just a public cost. In doing this, new anthropological approach to the past is adopted accentuating not so much on academic history but on places of memory, exemplifying different life facets of the past. There are two consequences following from this: (a) animation of the history, which has been turned into a 'living' past, and (b) discovering the plurality of the past: there are many pasts of different (sometimes contradictory) memory communities. This trend is also connected with the evolution of new museography, based on spectacle, narrativization and performativity.

In addition to these general trends, there are some specificities in Europe, which can be conceptualized as 'European model' of cultural heritage policies evolving in the framework of the European search for sustainable development.

\section{The European Model of Cultural Heritage Policy}

No doubts that the special place which cultural heritage occupies in the political agenda of the EU is determined by the master task given to Culture to turn the political union into a community by providing a common denominator of shared values as a ground for unified European identity. This is a fragile process of transformation of the European symbolic realm, a process of opening of the national political and personal ideational borders and still preserving a core of national identifications, accompanied by new uncertainties in front of the economic, social and migration challenges, and ongoing re-negotiations of the principles of the EU co-operation, at the same time. Thus the emerging European model of cultural heritage policy (CHP) is characterised by several specific features, namely: (1) Europeanisation of cultural heritage; (2) heritagisation of European culture(s); (3) development of European urbactivism as a fusion of top-down and bottom-up efforts; (4) connected with this process appearance of new transnational stakeholders; (5) emergence of various forms of participatory governance; (6) promoting and sustaining cultural heritage in Europe via special digital library Europeana.

${ }^{9}$ Faro Convention, Council of Europe Framework Convention on the Value of Cultural Heritage for Society, Cultural Heritage, Council of Europe Treaty Series 2005, No. 199, p. 2. 


\section{Europeanisation of cultural heritage}

One of the leading features of the European model of cultural heritage policy is the process of its 'europeanisation'. Certainly, this is a neologism, absurd to some extent, because the emergence of the idea of cultural heritage itself is correlative with the establishment of nation-states and crystallisation of national cultures, and for this reason the concept is inseparable from the national framework..$^{10}$

So, how to 'europeanise' the already existing heritages of different nations, with their deep imbeddedness in the national imagery, and their functioning - fixed to the national geographical and historical reference points? The answer of the European institutions is: by re-conceptualisation and highlighting the common heritage of Europe as "a shared source of remembrance, understanding, identity, cohesion and creativity." 11 By and large, this can happen by laying a new focus on the common roots and bringing to the fore all historical facts that exemplify co-operative spirit in Europe (from technologies and trade exchanges to religious, philosophical and artistic movements), and by backstaging everything that has once separated the Europeans: wars, rivalries and atrocities the evidences of which - if preserved - are exposed predominantly in the framework of the national historiographies. ${ }^{12}$ Certainly, this is a process of intensive time and space re-imagination, to use Benedict Anderson's term, resulting in broadening (extending in the space) and deepening (getting back in the history) of the idea of common European past, i.e. what is recognized as common in the history of Europe. The dominance of one particular narration about the past is defined by Laurajane Smith as authorized heritage discourse (AHD), which although does not entirely exclude subaltern uses and visions of heritage, still promotes "a consensus version of history by state-sanctioned cultural institutions and elites to regulate cultural and social tensions in the present." 13

Although the Article $3.3^{14}$ of the Lisbon Treaty is considered to lay the present legal foundation for co-operative cultural policies in Europe, actually the process has started much earlier by the Council of Europe with the European Cultural Convention, opened for signing in Paris on $19^{\text {th }}$ December 1954. The Convention refers to common heritage in two different ways: once, in the broadest possible ideational framework, outlined in the Preamble as the ideals and principles which are the common heritage whose safeguarding and realising will enable the achievement of its

${ }^{10}$ T. Lähdesmäki, The EU'S Explicit and Implicit Heritage Politics, "European Societies" 2014, Vol. 16 (3).

${ }^{11}$ Faro Convention, Council of Europe..., Article 3.

${ }^{12}$ A recent exception to this is a new cultural route revealing the actions of the Westen Allied Forces during the last phase of the Second World War - Liberation Route Europe, supported by the EU. Finally, the narrative of the route again accentuates on the historical lesson as a basis for present co-operation between European states thus finally suggesting a consensual vison of the dissonant past. See: http://liberationroute.com/liberation-route-europe [access: 10.10.2016].

${ }^{13}$ L. Smith, Uses of Heritage, London and New York 2006, p. 4.

${ }^{14}$ It stipulates that the European Union "shall respect its rich cultural and linguistic diversity and shall ensure that Europe's cultural heritage is safeguarded and enhanced." 
main aim: a greater unity. In this meaning European cultural heritage is commensurable with European culture per se. But there is a second, more specific notion, employed in the Convention. As Article 1 points out, "Each Contracting Party shall take appropriate measures to safeguard and to encourage the development of its national contribution to the common cultural heritage of Europe," these ideas being further specified in Article 5: "Each Contracting Party shall regard the objects of European cultural value placed under its control as integral parts of the common cultural heritage of Europe, shall take appropriate measures to safeguard them and shall ensure reasonable access thereto."15

The following polical documents elaborated and adopted by the $\mathrm{CoE}$ regarding European cultural heritage are consistently entering into further specificities concerning different kinds of heritage and the politics for their sustainable future (see Table 1).

Although the Council of Europe - unlike the EU - cannot make binding laws, nevertheless its consistent policies in the field of cultural heritage contributed much for the development of a legal framework enabling the international scientific, technical, legal and administrative co-operation in different fields of joint concern, ${ }^{16}$ which "remained firmly at the heart of European endeavours to find broadly applicable solutions to common problems." ${ }^{17}$ Certainly, this has been a fertile soile for the growth of the so called europeanisation of cultural heritage, turned into a center of the united-in-diversity cultural policies of the European Union, gradually taking a lead in the field.

This trend is granted by the fact that while national cultures are still prerogative of nation-states, the subject of cultural heritage, its preservation and sustainable use and development allow/require transnational regulatory standards and based on this true pan-European dimension, supported by a series of political documents and programs issued by the European Parliament (EP), the European Commission (EC), as well as by other Europe-wide intergovernmental and non-governmental stakeholders. This produced the effect of bringing to the fore the issues of heritage in different sectors of the European culture, society and economy, namely: Heritagisation of the European culture.

15 Council of Europe, European Cultural Convention (1954).

${ }^{16}$ In addition to the endorsement of legal instruments such as Conventions and Charters, the $\mathrm{CoE}$ has undertaken consequent initiatives like declaring 1975 for European Architectural Year; the adoption of resolutions and recommendations such as Resolution (76) 28, on 14 April 1976, concerning the adaptation of laws and regulations to the requirements of integrated conservation of the architectural heritage; Recommendation 880 (1979) of the Parliamentary Assembly of the Council of Europe on the conservation of the European architectural heritage; Recommendation No. R (80) 16 of the Committee of Ministers to member States on the specialised training of architects, town planners, civil engineers and landscape designers; Recommendation No. R (81) 13 of the Committee of Ministers, adopted on 1 July 1981, on action in aid of certain declining craft trades in the context of the craft activity. In 1987 the CoE launched the Cultural Routes Programme with the objective "to demonstrate, by means of a journey through space and time, how the heritage of the different countries and cultures of Europe contributes to a shared cultural heritage."

$17 \mathrm{~J}$. Bold, The documentation of the architectural heritage in Europe: A progress report, Council of Europe 1992, p. 10. 
Table 1. Main Legal Initiatives of the Council of Europe in the Field of Cultural Heritage

\begin{tabular}{|c|c|c|}
\hline Name of the initiative & Date / place of adoption & Main contribution \\
\hline $\begin{array}{l}\text { European Convention on the } \\
\text { Protection of the Archaeologi- } \\
\text { cal Heritage }\end{array}$ & 6 May 1969, London & $\begin{array}{l}\text { Raises the issues of authorization and control } \\
\text { of excavations; raise public awareness } \\
\text { of the historical and cultural value of the } \\
\text { archaeological heritage and the necessity to } \\
\text { preserve it. }\end{array}$ \\
\hline $\begin{array}{l}\text { European Charter of the Archi- } \\
\text { tectural Heritage }\end{array}$ & $\begin{array}{l}\text { 21-25 October } 1975, \\
\text { Amsterdam }\end{array}$ & $\begin{array}{l}\text { Underlines the multiple cultural, social } \\
\text { and economic values represented by historic } \\
\text { monuments, groups of old buildings } \\
\text { and interesting sites }\end{array}$ \\
\hline $\begin{array}{l}\text { European Convention on } \\
\text { Offences relating to Cultural } \\
\text { Property }\end{array}$ & 23 June 1985, Delphi & $\begin{array}{l}\text { Creates the basis of international legal frame- } \\
\text { work for protection of cultural property (in- } \\
\text { cluding cultural heritage) and criminalization } \\
\text { of the acts of offences of cultural property. }\end{array}$ \\
\hline $\begin{array}{l}\text { Convention for the Protection } \\
\text { of the Architectural Heritage } \\
\text { of Europe }\end{array}$ & 3 October 1985, Granada & $\begin{array}{l}\text { Introduces the principles of integrated } \\
\text { conservation; represents a next benchmark for } \\
\text { a common European policy for the conser- } \\
\text { vation and enhancement of the architectural } \\
\text { heritage. }\end{array}$ \\
\hline $\begin{array}{l}\text { European Convention } \\
\text { on the Protection of the } \\
\text { Archaeological Heritage }\end{array}$ & 16 January 1992 , Valletta & $\begin{array}{l}\text { Raise public awareness about the necessity of } \\
\text { protection of the archaeological heritage as } \\
\text { a source of the European collective memory } \\
\text { and as an instrument for historical and scien- } \\
\text { tific study. }\end{array}$ \\
\hline $\begin{array}{l}\text { European Landscape Conven- } \\
\text { tion }\end{array}$ & $\begin{array}{l}20 \text { October } 2000, \\
\text { Florence }\end{array}$ & $\begin{array}{l}\text { Introduces a new concept of cultural land- } \\
\text { scape as a cultural heritage, reflecting the } \\
\text { European identity and diversity; promotes } \\
\text { the protection, management and planning of } \\
\text { European landscapes and organises European } \\
\text { co-operation on landscape issues. }\end{array}$ \\
\hline $\begin{array}{l}\text { Framework Convention on the } \\
\text { Value of Cultural Heritage for } \\
\text { Society }\end{array}$ & 13 October 2005, Faro & $\begin{array}{l}\text { Introduces new relational concept of cultural } \\
\text { heritage and of 'heritage community', thus } \\
\text { opening the option for their internationaliza- } \\
\text { tion / Europeanisation. }\end{array}$ \\
\hline
\end{tabular}

Source: own research. 


\section{Heritagisation of the European culture}

According to some authors the term heritagisation ${ }^{18}$ was coined by Robert Hewison in 1987, by which he refers to the process of transformation of places to heritage sites ${ }^{19}$; others as Peter Jan Margry and Rodney Harrison claim that it was Kevin Walsh who first introduced the concept - in a derogatory sense as a process which reduces the past to few "acceptable national themes; real places - to tourist space," ${ }^{20}$ thus transforming objects and places from functional 'things' into objects of display and exhibition. ${ }^{21}$

Although the concept is dominated by spatial connotations, it has actually much broader coverage, including as suggested by Regina Bendix "the elevation of particular objects (art, monuments, landscapes, memorial sites) and practices (performances, music, rituals, and related cultural practices and memories) to the status of heritage as something to be consciously preserved for present and future generations." ${ }^{22}$ This process is necessarily selective, as not all cultural memory will gain this status. ${ }^{23}$ Although mobilized for different purposes, "the heritagization process carries an emotional resonance about underlying values that maintains social order, collective relationships and sense of belonging." ${ }^{24}$ Being an aspect of the post-industrial experience economy, heritagisation is a global phenomenon, ${ }^{25}$ but its scope and consistency, engaging different spheres of politics, economy, society and culture in Europe, is remarkable.

Among the political incentives, paving the road to shared European past, already visualized in the official EU imagery, such as in the design of the Euro currency, are the Raphael community action program (1997-2000), the European Heritage La-

${ }^{18}$ C. Sánchez-Carretero points out that heritagization has been European term with French doublette - patrimonialisation. See: C. Sánchez-Carretero, Significance and social value of cultural heritage: analyzing the fractures of heritage [in:] M.A. Rogerio-Candelera, M. Lazzari (Eds.), Science and Technology for the Conservation of Cultural Heritage, London 2013, pp. 387-392.

${ }_{19}$ O. Salemnik, Described, Inscribed, Written Off: Heritagisation as (Dis)connection [in:] $\mathrm{Ph}$. Taylor (Ed.), Connected and Disconnected in Viet Nam: Remaking Social Relations in a Postsocialist Nation, Canberra 2016, p. 316, http://press.anu.edu.au/wp-content/uploads/2016/03/ch093. pdf [access: 16.07.2016].

${ }^{20} \mathrm{~K}$. Walsh, The Representation of the Past: Museums and Heritage in the Postmodern World, London 1992, p. 4.

${ }^{21}$ R. Harrison, Heritage: Critical Approaches, London and New York 2013, p. 69.

${ }^{22} \mathrm{R}$. Bendix, Heritage between economy and politics: an assessment from the perspective of cultural anthropology [in:] L. Smith, N. Akagawa (Eds.), Intangible Heritage, London and New York 2009.

23 O. Salemnik, op.cit., p. 317.

${ }^{24}$ S. Ashley, Re-telling, Re-cognition, Re-stitution: Sikh Heritagization in Canada, Cultura, "International Journal of Philosophy of Culture and Axiology" 2014, Vol. 11 (2), p. 40, http://nrl. northumbria.ac.uk/18429/ [access: 12.08.2016].

${ }^{25}$ See for ex.: P.J. Margry, Memorializing a Controversial Politician: The "Heritigization" of a Materialized Vox Populi [in:] P.J. Margry, C. Sánches-Carretero (Eds.), Grassroot Memorials: The Politics of memorializing Traumatic Death, Berghahn Books 2011; S. Ashley, op.cit., O. Salemnik, op.cit. 
bel, European Capital of Culture, EU Prize for Contemporary Architecture, European Heritage Days, European Union prize for cultural heritage, operated as Europa Nostra Awards, Euromed Heritage programme, and the forthcoming in 2018 European Year of Cultural Heritage.

An indicative example of the heritagisation of the European culture, i.e. growing importance of heritage in the long-term European cultural policies and practices, is the evolution of European Capital of Culture Program. Although the heritage was not initially (or at least not explicitely) among its priorities, it was gradually repositioned and recently it gained visibility - together with the requirement for the "European dimension." Thus in the Decision No. 445/2014/EU of the European Parliament and of the Council of 16 April 2014 establishing a Union action for the European Capitals of Culture for the years 2020 to 2033, articles 1 \& 7 in the Preamble explicitely mention bringing common cultural heritage to the fore and promoting Europe's cultural heritage referring to the Treaty on the Functioning of the European Union (TFEU).

This trend is expressed also in the unification of the forces of various institutions and different sectors of society in their efforts to jointly reconstitute the vision of common European past, starting from the main stakeholders, the $\mathrm{CoE}$ and the EC, and ending with a multitude of newly founded pan-European NGOs and networks. For example, the European Heritage Days (EHD) launched by the Council of Europe (CoE) in 1991, since 1999 has been co-organized together with the European Commission (EC) concentrating on trans-national themes and cross-border activities. And vice versa, in 2002, the EC launched the European Union Prize for Cultural Heritage as a part of the implementation of the Culture 2000 program. The pan-European federation for cultural heritage Europa Nostra with representatives from over 200 heritage NGOs throughout Europe, was selected to run the prize scheme.

To make it clear, the both processes - europeanisation of cultural heritages in Europe, and heritagisation of European culture - are mutually intertwined and permeate into different sectors of European society through diverse European programs. As reported in the official website of the EC, "Cultural heritage is eligible for significant EU funding from 2014-2020 - including for conservation, digitization, infrastructure, research and skills - from several EU programmes - including the European Structural \& Investment Funds, Horizon 2020, Creative Europe, Erasmus+, Europe for Citizens. Policy collaboration on cultural heritage among EU member states continues to be pursued through the Council of Ministers for Education, Youth, Culture and Sports, and through the Open Method of Coordination." ${ }^{\prime 26}$

The climax of this process is the initiative "Towards an integrated approach to cultural heritage for Europe." ${ }^{27}$ It was prepared and opened for discussion in 2014 by

${ }^{26}$ EC (European Commission), Supporting the cultural heritage, http://ec.europa.eu/culture/ policy/culture-policies/cultural-heritage_en.htm [access: 15.08.2016].

27 See: Towards an Integrated Approach to Cultural Heritage in Europe, final, Communication from the Commission to the European Parliament, the Council, the European Economic and Social Committee and the Committee of the Regions, COM (2014) 477, http://ec.europa.eu/culture/library/ publications/2014-heritage-communication_en.pdf [access: 16.08.2016]. 
the Committee on Culture and Education, and consequently it aroused the opinions of the Committee of Regions and the Committee of Transport and Tourism, expressing interest in a concerted action in this field. As described in the Introduction of the conclusive Communication of the European Parliament (EP), it "presents the EU's approach to heritage across different policy areas [...] the tools available at EU level, complementing national and regional programmes [...], the measures available to strengthen policy cooperation at different levels, and projects being developed to support new models of heritage governance. ${ }^{.28}$ The overall aim is to help Member States and stakeholders make the most of the significant support for heritage available under EU instruments, progress towards "a more integrated approach at national and EU level, and ultimately make Europe a laboratory for heritage based innovation." 29

The document acknowledges the transsectoral effects of cultural heritage which affects regional development, social cohesion, agriculture, maritime affairs, the environment, tourism, education, the digital agenda, external relations, customs cooperation and research and innovation, and therefore it is addressed in different EU policies, including those concerning above-mentioned sectors. In order to counter the fragmentation in this area, the Communication draws attention to the need to improve the statistics and research based on a holistic vision of cultural heritage.$^{30}$ While these are EU-led top-down processes, there is a simultaneous bottom-up movement, initiated by local communities and towns aiming at sustainable development with the means of culture. This shall be called with another neologism referring to specific 'bottom-up' movements, integrating art and social activism, and supported 'topdown' by different European programs.

\section{European urbactivism}

Urbactivism as specific urban artivism, ${ }^{31}$ i.e. cultural and artistic activism for social purposes flourishing in cities, based on new 'green' values, is stemming from local communities but it is realised with the support of various European programs - URBAN, URBACT, JESSICA and JEREMIE, and other programmes at regional and national levels, including independent initiatives of groups of towns and cities as

${ }^{28}$ See: http://www.europarl.europa.eu/sides/getDoc.do?type=REPORT\&reference=A82015-0207\&language=EN [access: 16.08.2016].

${ }^{29}$ Ibidem.

${ }^{30}$ The project "Cultural Heritage Counts for Europe: Towards a European Index for Valuing Cultural Heritage" (2015), can be regarded as a prompt respond to this information deficit. Available at: http://blogs.encatc.org/culturalheritagecountsforeurope//wp-content/uploads/2015/06/CHCfE_FULL-REPORT_v2.pdf [access: 16.06.2016].

${ }^{31}$ The notion artivism is introduced by the Sloveniam sociologist Aldo Milohnić (2005) as a hybrid of art and activism. See more in: M. Dragićević Šešić, A. Brkić, J. Matejić, Mobilizing urban neighbourhoods: Artivism, identity, and cultural sustainability [in:] S. Hristova et al. (Eds.), Culture and Sustainability in European Cities: Imagining Europolis, Lodon-NewYork 2015, p. 193. 
CENTROPE and the EuRegio Salzburg - Berchtesgadener Land - Traunstein (ESPON 2013).

There are two interpretative clues to this issue: according to the first one, this phenomenon can be regarded as a part of a global trend to increased participatory public engagement which can be observed mainly in the developed West. ${ }^{32}$ The second one suggests a critical interpretation, insisting that it is installed through different European programs, and for this reason, it is not authentic: it is described as politics of 'governmentality' of heritage, including "the rhetoric and practice through which the EU's top-down policies are made to look as bottom-up attempts." 33

This paper offers a third perspective: the bottom-up urbactivism is based on much deeper concerns of European citisens - those of shared responsibility of risk society. Their efforts - whether in the field of culture or in any other concerted action are aiming at more sustainable way of life. The co-operatives in Germany, recognized as bio-village movement, for example, are transcending their initial goals of renewable energy generation and re-destribution and act jointly in other cases as well. In addition, the bottom-up cooperation and association between Euroepan citizens is enabled by the development of social media and Internet, giving rise to the so called 'Culture $3.0^{\prime 34}$ where the boundaries between users and producers are definitely merging and all are produsers.

One of the brightest examples of such movement is the Aalborg Charter of European Cities and Towns towards Sustainability (1994) which in its opening declaration defines the founding value of culture and heritage for the European identity: "We, European cities and towns... guardians of culture, heritage and tradition." ${ }^{35}$ The Charter regards sustainability as a creative, local, balance-seeking process, extending into all areas of local decision-making. Thus the management of a city is built around the information collected through such a process, in which citizens may make informed choices. Through a management process rooted in sustainability, decisions may be made which not only represent the interests of current stakeholders, but also of future generations. ${ }^{36}$ This gives additional stimulus to different forms of participatory governance of cultural heritage as a meeting point between bottom-up processes and top-down politics, stimulating the social integration and economic vitality of cities. ${ }^{37}$ In this perspective, cooperative management of cultural heritage is one of the earliest institutional forms of participatory governance, stemming from the end of the $19^{\text {th }}$ century.

${ }^{32}$ N. Mahony, H.C. Stephansen, The frontiers of participatory public engagement, "European Journal of Cultural Studies" 2016, pp.1-15.

33 T. Lähdesmäki, op.cit., p. 14.

${ }^{34}$ See: P.-L. Sacco, Culture 3.0 - a new perspective for the EU 2014-2020 structural funds programming, 2011, http://www.culturalpolicies.net/web/files/241/en/Sacco_culture-3-0_CCIs-Local-and-Regional-Development_final.pdf [access: 12.05.2016].

${ }_{35}$ Aalborg Charter of European Cities and Towns towards Sustainability, 1994, http://www. sustainablecities.eu/fileadmin/content/JOIN/Aalborg_Charter_english_1_.pdf [access: 08.07.2016].

36 Ibidem.

${ }^{37}$ S. Hristova, op.cit., pp. 45-47. 
Enhancing participatory governance of cultural heritage is foreseen in the European Plan for Culture (2015-2018) with identification of innovative approaches to the multilevel governance of tangible, intangible and digital heritage which involve the public sector, private stakeholders and the civil society. ${ }^{38}$

\section{New transnational stakeholders}

The increasing number of European networks and associations in the field of cultural heritage can be described as continuous proliferation, as some of the organizations are stemming from others, thus constituting ever growing supra-network. Here we shall consider just few of them with already proved impact in the sector, with different regional and international scope of action and interests:

- Europa Nostra is a pan-European network for safeguarding of Europe's cultural and natural heritage, composed of 250 member organisations (heritage associations and foundations with a combined membership of more than 5 million people), 150 associated organisations (governmental bodies, local authorities and corporations) and 1,500 individual members. It was founded in 1963 in Paris, in the office of the CoE; ${ }^{39}$

- The European Association of Historic Towns and Regions, formed by the Council of Europe in 1999 as part of the initiative "Europe - A Common Heritage" consolidates over 1,000 historic and heritage towns, cities and regions in 30 European countries; ${ }^{40}$

- The European Heritage Alliance 3.3, an informal European sectoral platform composed of 33 European or international networks and organisations active in the wider field of cultural heritage, was launched in June 2011 on the occasion of the European Heritage Congress, organized by Europa Nostra in Amsterdam; ${ }^{41}$

- The European Historic Houses Association, an umbrella organisation gathering 22 national associations of historic houses and 1 observer country established in 1985 under Dutch Law, but consulted by the European Commission and the European Council; ${ }^{42}$

- HEREIN, a complex project of the CoE for observatory on policies of the European heritage. It is founded as intergovernmental establishment in 2010, promoting and fostering the exchange and collection of information related to financing mechanisms, legislations, documentation systems, integrated conservation strategies and awareness-raising actions. It combines the contribu-

38 Work Plan for Culture 2015-2018, http://data.consilium.europa.eu/doc/document/ST-160942014-INIT/en/pdf [access: 20.04.2016].

39 See: http://www.europanostra.org/ [access: 20.04.2016].

${ }^{40}$ See: http://www.historic-towns.org/html/about.html [access: 20.04.2016].

${ }^{41}$ See: http://europeanheritagealliance.eu/ [access: 20.04.2016].

${ }^{42}$ See: http://www.europeanhistorichouses.eu/ [access: 20.04.2016]. 
tion of HEREIN Network formed by the public administrations from over 44 Member States responsible for national policies in the field of cultural heritage; and voluntary contributions from the International Association of the European Heritage Network (HEREIN AISBL), bringing together government representatives responsible for cultural heritage from Belgium (Wallonia), Finland, France, Greece, Slovenia, Switzerland and the United Kingdom. ${ }^{43}$

These networks work complementarily to the Council of Europe, the European Commission and the European Council, supported by the expertise of different thematic working groups, and by the specialized consultative body European Heritage Heads Forum. ${ }^{44}$ Besides the process of enlargening of the pan-European networks there runs also a parallel process of organizing regional associations, i.e. Centrope, encompassing CEE-countries, or based on specific forms of co-operation, as the mentioned above HEREIN AISBL. If cultural heritage is a field also of manifestation of power (symbolic, political and economic), this could be a sign of power redistribution and interests re-grouping within the existing European framework.

\section{Sustaining heritage through its digitization: Europeana}

Sustaining the heritage is a process of maintainance, safeguarding and using it according to its own carrying capacity. This is a fragile balance where underuse of heritage is undesirable as it would be doomed to oblivion while overuse is threatening with destruction or at least with damage. Other difficult balances are how to make heritage work for the community but not to exploit it; and how to grant conservation and preservation of the spirit of the heritage site while adopting an acceptable degree of change and adaptive reuse.

Digitisation gives a promise for a second 'eternal' life to heritage and the Europeana cultural platform ${ }^{45}$ is another distinct element of the European model of cultural heritage management. As noted in the Communication: Towards an Integrated Approach to Cultural Heritage in Europe, it now provides on-line access to about 30 million cultural objects from more than 2,500 organisations: the resources of Europe's cultural institutions are now more internet-friendly and more widely re-usable. Europeana helps to develop and implement standards and interoperability in this area and provides a space where culture professionals share digital expertise. The Europeana Regia project includes more than 1,000 digitised rare manuscripts from the Middle Ages and the Renaissance. Others focus on the potential for creative re-use of digital cultural material, such as Europeana Creative and Europeana Space.

Although Europeana successfully demonstrates how the new technologies for digitization of European cultural heritage which leads to the extension of what was

${ }^{43}$ See: http://www.coe.int/t/dg4/cultureheritage/heritage/Herein/Default_en.asp [access: 20.04.2016].

${ }^{44}$ See: http://www.ehhf.eu/ [access: 20.04.2016].

${ }^{45}$ See: http://www.europeana.eu [access: 20.04.2016]. 
defined by Mauris Halbwachs as 'communicative memory' of Europe, and provides valuable opportunities for easy access, it cannot cancel the questions about the physical sustaining of the tangible and intangible heritage of Europe, nor it can blur the fact of the digital 'domination' of certain European cultures becoming representative of the digital memory of Europe itself.

\section{European cultural heritage - source of identity, social cohesion and economic vitality?}

The present review of the European policies towards cultural heritages of Europe - and more generally towards the European culture, reveal the raising political expectations which extend into all possible spheres of functional society, assuming heritage to solve the growing problems of economy, youth unemployment, social polarization and subversive anomia. Certainly, this is one of the most powerful economic and symbolic resources of Europe with huge emotional resonance, and for this reason, one of the most efficient tools for European integration, but how realistic are all these expectations finally?

Obviously, the efforts of European institutions tend towards mobilization and intertwining of heritage politics into different EU's policies and besides the cultural field, they extend in regional and urban development and regeneration, administered through European Social Fund (ESF), the European Regional Development Fund (ERDF), and several recent EU-funded research projects (e.g., implemented as a part of the Joint Programming Initiative on Cultural Heritage), which have explored the issues of the preservation, meaning making, and use of cultural heritage as a source of European identity.

In this analysis however we did not make an account of the role of other global stakeholders in the field of cultural heritage as ICOMOS and UNESCO whose work preceded and pre-conditioned the political efforts focused entirely on Europe. On the other hand, they created multiple cultural and political resonance for the European thinkers, which also were collaborators in this process. The Venice Charter (1964), for example, setting the international standards for the conservation and restoration of monuments and sites, ${ }^{46}$ was prepared by a committee dominated by Europeans with only four non-European members out of 23. This also reveals the global synergies in the field of cultural heritage based on the world-wide dissemination of European standards and visions.

Finally, all described trends leave open the question about the authenticity and the acceptable compromise in the process of re-imagination of cultural heritage of Europe where new symbolic power redistributions imperceptibly grow.

${ }^{46}$ See: https://en.wikipedia.org/wiki/Venice_Charter [access: 20.04.2016]. 


\section{Bibliography}

Ashley S., Re-telling, Re-cognition, Re-stitution: Sikh Heritagization in Canada, Cultura, "International Journal of Philosophy of Culture and Axiology" 2014, Vol. 11 (2), pp. 39-58, http://nrl. northumbria.ac.uk/18429/ [access: 14.08.2016].

Beck U., Risk Society: Towards a New Modernity, New Delhi 1992.

Bendix R., Heritage between economy and politics: an assessment from the perspective of cultural anthropology [in:] L. Smith, N. Akagawa (Eds.), Intangible Heritage, London and New York 2009.

Bold J., The documentation of the architectural heritage in Europe: A progress report, Council of Europe 1992.

Dragićević Šešić M., Brkić A., Matejić J., Mobilizing urban neighbourhoods: Artivism, identity, and cultural sustainability [in:] S. Hristova et al. (Eds.), Culture and Sustainability in European Cities: Imagining Europolis, London and NewYork 2015.

Greffe X., Heritage conservation as a driving force for development [in:] Heritage and beyond, Council of Europe, December 2009.

Harrison R., Heritage: Critical Approaches, London and New York 2013.

Hewison R., The Heritage Industry: Britain in a Climate of Decline, London 1987.

Hristova S., We, European cities and towns: the role of culture for the evolving European model of urban sustainability [in:] Hristova et al. (Eds.), Culture and Sustainability in European Cities: Imagining Europolis, Lodon and New York 2015.

Lähdesmäki T., The EU'S Explicit and Implicit Heritage Politics, "European Societies" 2014, Vol. 16 (3).

Lefebvre H., The Urban Revolution, Minneapolis and London [1970] 2003.

Mahony N., Stephansen H.C., The frontiers of participatory public engagement, "European Journal of Cultural Studies" 2016, pp.1-15.

Margry P.J., Memorializing a Controversial Politician: The "Heritigization" of a Materialized Vox Populi [in:] P.J. Margry, C. Sánches-Carretero (Eds.), Grassroot Memorials: The Politics of memorializing Traumatic Death, Berghahn Books 2011.

Paludan-Müller C., Europe - A constrained and fragmented space on the edge of the continental landmasses. Crossroad, battlefield and melting pot [in:] Heritage and beyond, Council of Europe, December 2009.

Sacco P.-L., Culture 3.0 - a new perspective for the EU 2014-2020 structural funds programming, 2011, http://www.culturalpolicies.net/web/files/241/en/Sacco_culture-3-0_CCIs-Local-andRegional-Development_final.pdf [access: 12.05.2016].

Salemnik O., Described, Inscribed, Written Off: Heritagisation as (Dis)connection [in:] Ph. Taylor (Ed.), Connected and Disconnected in Viet Nam: Remaking Social Relations in a Post-socialist Nation, Canberra 2016, http://press.anu.edu.au/wp-content/uploads/2016/03/ch093.pdf [access: 16.07.2016].

Sánchez-Carretero C., Significance and social value of cultural heritage: analyzing the fractures of heritage [in:] M.A. Rogerio-Candelera, M. Lazzari (Eds.), Science and Technology for the Conservation of Cultural Heritage, London 2013.

Smith L., Uses of Heritage, London and New York 2006.

Walsh K., The Representation of the Past: Museums and Heritage in the Postmodern World, London 1992.

Zukin S., The Cultures of Cities, Oxford and Malden MA 1995.

\section{Official documents and reports:}

Aalborg Charter of European Cities and Towns towards Sustainability, 1994, http://www.sustainablecities.eu/fileadmin/content/JOIN/Aalborg_Charter_english_1_.pdf [access: 08.07.2016]. 
Architectural heritage: inventory and documentation methods in Europe. Proceedings. European colloquy organised by the Council of Europe and the French Ministry for Education and Culture, Direction du patrimoine, Nantes, 28-31 October 1992.

Decision No. 445/2014/EU of the European Parliament and of the Council of 16 April 2014 establishing a Union action for the European Capitals of Culture for the years 2020 to 2033 and repealing Decision No. 1622/2006/EC, http://eur-lex.europa.eu/legal-content/EN/ NOT/?uri=CELEX:32014D0445 [access: 15.08.2016].

EC (European Commission), Supporting the cultural heritage, http://ec.europa.eu/culture/policy/ culture-policies/cultural-heritage_en.htm [access: 15.08.2016].

EC (European Commission), Getting Cultural Heritage to Work for Europe, 2015.

EC (European Commission: DG EAC), Mapping of Cultural Heritage actions in European Union policies, programmes and activities, 2014, http://ec.europa.eu/culture/library/reports/2014heritage-mapping_en.pdf [access: 16.08.2016].

EP (European Parliament: Committee on Culture and Education), Report towards an Integrated Approach to Cultural Heritage for Europe. 2014/2149(INI) http://www.europarl.europa.eu/sides/ getDoc.do?type=REPORT\&reference=A8-2015-0207\&language=EN [access: 16.08.2016].

ICOMOS (International Council of Monuments and Sites) International charter for the conservation and restoration of monuments and sites (The Venice Charter 1964), https://www.icomos. org/charters/venice_e.pdf [access: 16.08.2016].

Opinion of the European Committee of the Regions - Towards an integrated approach to cultural heritage for Europe, "Official Journal of the European Union" 2015/C 195/04, 12.6.2015, C 195/22-29.

Towards an Integrated Approach to Cultural Heritage in Europe, final, Communication from the Commission to the European Parliament, the Council, the European Economic and Social Committee and the Committee of the Regions, COM (2014) 477, http://ec.europa.eu/culture/library/publications/2014-heritage-communication_en.pdf [access: 16.08.2016].

Conclusions on cultural heritage as a strategic resource for a sustainable Europe. Education, Youth, Culture and Sport Council Meeting, Brussels, 20 May 2014, https://www.consilium.europa.eu/uedocs/cms_data/docs/pressdata/en/educ/142705.pdf [access: 18.08.2016].

Council of Europe, European Cultural Convention (1954), Work Plan for Culture 2015-2018, http:// data.consilium.europa.eu/doc/document/ST-16094-2014-INIT/en/pdf [access: 17.08.2016].

World Commission on Environment and Development (WCED), Our Common Future. Report of the Brundtland Commission, Oxford 1987.

Faro Convention, Council of Europe Framework Convention on the Value of Cultural Heritage for Society, Cultural Heritage, Council of Europe Treaty Series 2005, No. 199. 